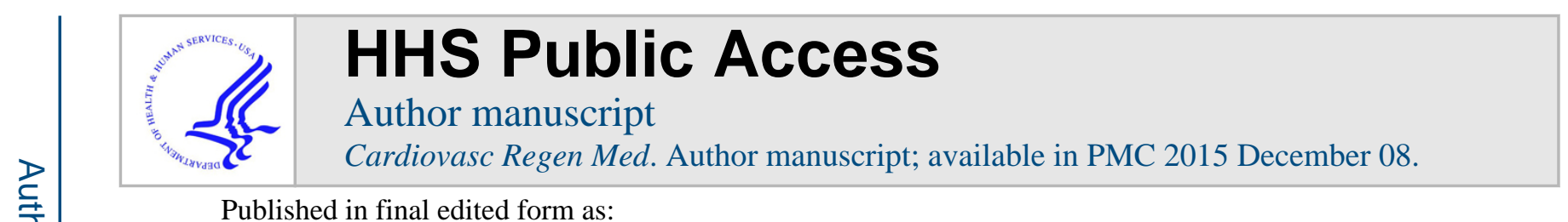

Published in final edited form as:

Cardiovasc Regen Med. 2015 ; 2: . doi:10.14800/crm.997.

\title{
Inhaled matters of the heart
}

\author{
Ahmed Zaky ${ }^{1,2}$, Aftab Ahmad ${ }^{1}$, Louis J Dell'Italia², Leila Jahromi ${ }^{1}$, Lee Ann Reisenberg1, \\ Sadis Matalon ${ }^{1}$, and Shama Ahmad ${ }^{1}$ \\ ${ }^{1}$ Department of Anesthesiology and Perioperative Medicine, University of Alabama at \\ Birmingham, Alabama \\ 2Department of Medicine, Birmingham Veteran Affairs Medical Center, Birmingham, Alabama and \\ Division of Cardiovascular Disease, University of Alabama Medical Center, Birmingham, Alabama
}

\section{Abstract}

Inhalations of atmospheric pollutants, especially particulate matters, are known to cause severe cardiac effects and to exacerbate preexisting heart disease. Heart failure is an important sequellae of gaseous inhalation such as that of carbon monoxide. Similarly, other gases such as sulphur dioxide are known to cause detrimental cardiovascular events. However, mechanisms of these cardiac toxicities are so far unknown. Increased susceptibility of the heart to oxidative stress may play a role. Low levels of antioxidants in the heart as compared to other organs and high levels of reactive oxygen species produced due to the high energetic demand and metabolic rate in cardiac muscle are important in rendering this susceptibility. Acute inhalation of high concentrations of halogen gases is often fatal. Severe respiratory injury and distress occurs upon inhalation of halogens gases, such as chlorine and bromine; however, studies on their cardiac effects are scant. We have demonstrated that inhalation of high concentrations of halogen gases cause significant cardiac injury, dysfunction, and failure that can be critical in causing mortalities following exposures. Our studies also demonstrated that cardiac dysfunction occurs as a result of a direct insult independent of coexisting hypoxia, since it is not fully reversed by oxygen supplementation. Therefore, studies on offsite organ effects of inhaled toxic gases can impact development of treatment strategies upon accidental or deliberate exposures to these agents. Here we summarize the knowledge of cardiovascular effects of common inhaled toxic gases with the intent to highlight the importance of consideration of cardiac symptoms while treating the victims.

\section{Keywords}

Inhaled gases; halogens; sulphur dioxide; cardiac dysfunction

\section{Introduction}

Many studies have been performed to investigate the cellular mechanisms of inhaled gasinduced injury to pulmonary tissues, however, very few have investigated the effect on cardiac tissue. Toxic gases such as halogens with a relatively higher water-solubility (e.g. $\mathrm{Cl}_{2}$ ) are most readily dissolved in the upper airways and can lead to irritation of mouth and 
airway mucosa. In contrast, agents with relatively lower water-solubility, such as bromine, can enter the deeper structures causing injury to the distal airways and the alveolar sac. In both cases the more stable secondary reactants can be absorbed into the circulation and reach other tissues and organs such as the heart ${ }^{[1]}$. The heart is the first recipient of the lung drainage. It is also a highly active pump that has a high metabolic rate to meet the highenergy demand. The excessive metabolic demand of the myocardium leads to increased rate of free radical production. The paucity of superoxide dismutase, catalase, and glutathione peroxidase in the heart makes it further susceptible to oxidative injury ${ }^{[2,3]}$. Circulating halogen reactants contribute to the additional burden on the heart by damaging important intracellular calcium $\left(\mathrm{Ca}^{2+}\right)$ regulators such as sarcoendoplasmic reticulum ATPase (SERCA) and causing cytosolic $\mathrm{Ca}^{2+}$ overload ${ }^{[1]}$. Excessive cytosolic $\mathrm{Ca}^{2+}$ cause mitochondrial production of reactive oxygen species ${ }^{[4,5]}$. Mitochondrial ROS can itself perturb the cytosolic $\mathrm{Ca}^{2+}$, cause cytoskeletal damage and lead to cardiac dysfunction ${ }^{[6,7]}$. Chlorine exposure increases cytosolic $\mathrm{Ca}^{2+}$ in pulmonary smooth muscle cells suggesting a similar set of mitochondrial damage and events of ROS production precede in the lung ${ }^{[8]}$. Therefore, toxic inhalational injury is caused through a variety of mechanisms including direct injury of the respiratory tract mucosa, respiratory asphyxiation, oxidative stress and systemic absorption of the reactants ${ }^{[1,9]}$. Understanding the mechanisms of cardiac tissue injury by inhaled toxic gases is crucial for developing effective therapeutic countermeasures.

The aim of this manuscript is to review the experimentally or clinically described cardiovascular effects of common toxic gases such as chlorine, bromine, ozone, carbon monoxide and sulfur dioxide. Although they may not have a common mechanism of action, understanding the events (acute or chronic) leading to the cardiotoxicity is important. Environmental pollutants especially airborne particulates have already been widely investigated for their cardiopulmonary toxicity and will not be covered here.

\section{Chlorine}

Chlorine is a yellow-green gas classified as an inhalational toxin. Most common exposures to chlorine gas are accidental, including release of chlorine vapor at swimming pools, exposure to household cleaning products and transportation mishaps (Table 1) ${ }^{[1,10,11]}$. Use of chlorine as a chemical weapon was first proposed in World War I and continues as a chemical threat agent ${ }^{[1,12,13]}$ (April 2015: $100^{\text {th }}$ anniversary).

Chlorine is a strong oxidizing agent and has high reactivity with water. Inhalational injury precipitated by chlorine in humans and experimentally have been reviewed extensively by White and Martin ${ }^{[14]}$. The primary site of action of chlorine gas is the epithelial cell surface of pulmonary tissue ${ }^{[15]}$. Pulmonary damage ranges from mild respiratory membrane irritation to non-cardiogenic pulmonary edema characteristic of acute respiratory distress syndrome (ARDS), and in some cases death ${ }^{[8,10,16-32]}$. The Majority of patients exposed to chlorine present with cough, dyspnea, and eye and throat irritation ${ }^{[10,21,33]}$. Because of the higher solubility of chlorine gas in water it can easily be dissolved in the epithelial lining fluid forming $\mathrm{HOCl}$ which may react with targets on cell surface directly with the cell membrane or matrix. Either $\mathrm{Cl}_{2}$ or $(\mathrm{HOCl})$ may react with reactive oxygen species (ROS) creating powerful oxygen free radicals that mix with a variety of biomolecules in the 
epithelium including ascorbate, reduced glutathione, sulfur containing amino acids such as cysteine and methionine, histidine, and side chains of tryptophan, lysine, and tyrosine ${ }^{[34]}[35][1,12,15]$. Other studies have shown that variations in inhaled concentrations of chlorine determine the site of action (upper airway epithelium versus alveolar epithelium), severity of injury, and reversibility of the damage [34] [36] [37]. Lower concentrations (less than $50 \mathrm{ppm}$ ) may affect the upper airway resulting in reversible bronchospasm, and higher concentrations (more than $50 \mathrm{ppm}$, mostly in industrial accidents or deliberate warfare attacks) may cause significant upper airway injury followed by alveolar damage [38].

Although chlorine gas respiratory toxicity has been extensively studied, reports of cardiac effects of chlorine inhalation are scarce and further studies are needed to explore cellular and molecular changes in the cardiac tissue, secondary to chlorine inhalation ${ }^{[39]}$. Known cardiac effects of chlorine exposure to the heart include arrhythmia (in the form of sinus tachycardia ${ }^{[10,11,40,41]}$, sinus bradycardia ${ }^{[1,20]}$, extra systoles ${ }^{[11]}$ ) myocardial infarction ${ }^{[42]}$ and cardiac arrest ${ }^{[22,40]}$. Cardiomegaly was observed in autopsy of about $90 \%$ of victims that died due to chlorine inhalation ${ }^{[14]}$. Despite these reports it is still unclear whether cardiac complications after inhalation of chlorine gas result from a direct toxic effect of chlorine on cardiomyocytes or they are secondary to respiratory epithelial damage and elevated pulmonary vascular resistance and hypoxia ${ }^{[43]}$. Yet, chlorine gas inhalation results in injury to both respiratory and cardiovascular systems $[1,15,30,44]$.

It has been shown that the harmful effects of inhaled toxic gases is not limited to the respiratory epithelium, but can also promote endothelial dysfunction in the systemic vasculature leading to cardiovascular diseases such as atherosclerosis and myocardial infarction [39], suggesting systemic release of deleterious factors from the lung injury. The pulmonary vascular bed has an extensive surface area and thus provides a large reservoir for release. The left heart is the first recipient of the pulmonary drainage and thus delivery into the coronary arteries. Environmental irritants such as chlorine can disturb the cardiovascular system by affecting nitric oxide (NO) signaling pathways resulting in endothelial disruption ${ }^{[39,45]}$. NO is an endogenous vasodilator derived from L-arginine ${ }^{[39]}$. Physiologic roles of $\mathrm{NO}$ are: regulating cellular respiration, maintaining an anti-inflammatory, antithrombotic (fibrinolysis), antioxidant, and anti-smooth muscle proliferation state ${ }^{[39]}$. Therefore, any disruption of this pathway can contribute to significant cardiovascular damage ${ }^{[39]}$. Daugherty et al., $1994{ }^{[46]}$ hypothesized for the first time that oxidation of lowdensity lipoproteins (LDL) catalyzed by myeloperoxidase (MPO) contributes to the vessel wall inflammation, promoting atherosclerosis ${ }^{[46,47]}$. Since then, many studies have confirmed that different oxidants such as reactive oxygen species, nitrogen species as well as $\mathrm{HOCl}$ can modify specific proteins on LDL and high-density lipoproteins (HDL) in human atheroma, and convert these proteins to pro-atherogenic molecules $[39,47,48]$. $\mathrm{HOCl}$ is a powerful oxidant with antibacterial properties that are important in host defense mechanisms ${ }^{[49]}$. MPO, which is released from activated leukocytes, catalyzes the reaction between $\mathrm{H}_{2} \mathrm{O}_{2}$ and $\mathrm{Cl}$ - to generate $\mathrm{HOCl}{ }^{[49]}$. However, excessive production of $\mathrm{HOCl}$, such as during chlorine inhalation, can further add to vascular tissue damage ${ }^{[47,49]}$. Therefore $\mathrm{NO}$ and $\mathrm{HOCl}$ could play a role in mediating chlorine-induced cardiovascular toxicity. 
Being the initiator of the heartbeat, intracellular calcium $\left(\mathrm{Ca}^{2+}\right)$ is the most important ion for cardiac function ${ }^{[50]} . \mathrm{Ca}^{2+}$ release from the sarcoplasmic reticulum (SR) is required for excitation-contraction coupling of cardiomyocytes that orchestrates cardiac contraction and relaxation. Optimal cytosolic $\mathrm{Ca}^{2+}$ content is critical for mitochondrial function, which is the source of cardiac energy required for contractility. However, excessive and unchecked cytosolic $\mathrm{Ca}^{2+}$ accumulation can result in mitochondrial production of reactive oxygen species severe enough to lead to heart failure ${ }^{[51-53]}$. The sarco/endoplasmic reticulum $\mathrm{Ca}^{2+}-$ ATPase (SERCA) plays a critical role in regulating cardiac intracellular $\mathrm{Ca}^{2+}$ homeostasis by mediating the transport of cytosolic $\mathrm{Ca}^{2+}$ into the sarco/endoplasmic reticulum at diastole and hence, lowering intracellular $\mathrm{Ca}^{2+}$ levels ${ }^{[1,54]}$. Activity of SERCA is susceptible to oxidants such as hypochlorous acid $(\mathrm{HOCl})$, a product of chlorine and water ${ }^{[1,54]}$. It was previously shown that exposure to $\mathrm{HOCl}$ decreases SERCA2 (the cardiac isoform) activity via irreversible oxidation of thiol groups on SERCA protein and increases cytosolic $\mathrm{Ca}^{2+}$ levels in endothelial cells of the coronary artery ${ }^{[54]}$. We have shown that acute exposure to high chlorine concentration in rats reduces cardiac SERCA activity via chlorination of tyrosines and oxidation of an important cysteine residue ${ }^{[1]}$ (Figure 1). We demonstrated that markers of cardiac muscle injury and reactive chlorine intermediates (chloramines) were increased in the blood stream after chlorine exposure and that total cardiac ATP content was significantly reduced ${ }^{[1]}$. We believe that reduced SERCA activity was a primary effect of chlorine reactants on heart tissue and not secondary to tissue hypoxia (due to lung injury), because exposure of cardiomyocytes to hypoxia for the same duration of time did not lead to a reduction in SERCA activity. We also demonstrated that oxygen supplementation only partially reversed chlorine-induced cardiac dysfunction ${ }^{[1,44]}$. Using ex vivo perfused heart model we demonstrated loss of contractile function by chloramines, a potential chlorine reactant generated in circulation of chlorine-inhaling animals. Chlorine by-products can act in several ways including 1 ) direct modification of important enzymes; 2) causing increased oxidative stress by generating reactive oxygen species; 3 ) enhancing pro-inflammatory pathways; and 4) increasing activity of tissue damaging proteases such as calpains and chymases in heart. These and potentially other mechanisms may acutely impair cardiac function or chronically inhibit the cardiac injury repair process ${ }^{[55]}$. Further studies are needed to evaluate chronic effects of chlorine inhalation on cardiac function.

\section{Bromine}

Another common industrial halogen, bromine $\left(\mathrm{Br}_{2}\right)$, is a highly reactive 'inhalational' threat agent that can spread both as liquid and as fumes ${ }^{[56]}$. It causes extensive morbidity and mortality in exposed populations ${ }^{[56,57]}$. It is also one of the most common toxic gases that are incriminated in causing respiratory damage upon inhalation. Like $\mathrm{Cl}_{2}, \mathrm{Br}_{2}$ inhalation causes skin and airway burns, severe respiratory symptoms and it's 'immediately dangerous to life and health' concentrations are even lower than $\mathrm{Cl}_{2}{ }^{[56,58,59]}$. However, at similar concentrations and duration of exposure, $\mathrm{Cl}_{2}$-induced toxicity was greater than $\mathrm{Br}_{2}$ in mice ${ }^{[60]}$. $\mathrm{Br}_{2}$ also reacts with tissue components such as the respiratory epithelium to liberate reactive oxygen species and tissue damage. In addition, hydrobromic acid $(\mathrm{HBr})$ and hypobromous acid $(\mathrm{HOBr})$ formed on the moist surface contribute to tissue injury. At high concentrations $\mathrm{Br}_{2}$ replaces atmospheric oxygen and its toxicity depends on confinement of 
exposure area, concentration, length of exposure, age and preexisting medical condition of the victims. Along with respiratory, gastrointestinal and central nervous symptoms, severe cardiovascular morbidities resulting from hypoxemia, and cardiac arrhythmias severe enough to progress to cardiac arrest were observed in people with acute inhalational $\mathrm{Br}_{2}$ exposure ${ }^{[56]}$. Chronic effects such as development of cardiomyopathy were also observed following $\mathrm{Br}_{2}$ inhalation ${ }^{[56]}$. Although $\mathrm{Br}_{2}$ ion and brominated compounds may persist in circulation for days following exposure in industrial workers and experimental animals, the mechanism of $\mathrm{Br}_{2}$ gas cardiovascular toxicity are thus far unexplored [61,62].

\section{Sulfur dioxide}

Sulfur dioxide $\left(\mathrm{SO}_{2}\right)$ is one of the most toxic gases in air-polluted areas ${ }^{[63,64]}$. It is commonly released in the atmosphere from fossil fuel combustion ${ }^{[65]}$. Because of high solubility in water, $\mathrm{SO}_{2}$ can be easily hydrated in respiratory mucosa to form sulfurous acid and its reactants such as bisulfite and sulfite ions ${ }^{[66-68]}$. These reactants may cause allergic reactions in the respiratory tract or can be reabsorbed into the blood and other body fluids and affect various organs in the body ${ }^{[67,68]}$. $\mathrm{SO}_{2}$ is known to cause acute adverse effects on the human cardiovascular system ${ }^{[64,69-71]}$ (Table 2). High concentrations of $\mathrm{SO}_{2}$ inhalation cause mortality due to cardiopulmonary dysfunction ${ }^{[72]}$. Exposure to $\mathrm{SO}_{2}$ is associated with an increased mortality people with underlying lung diseases such as chronic obstructive pulmonary disease (COPD) ${ }^{[69,73]}$.

Little knowledge is available about the molecular mechanisms of $\mathrm{SO}_{2}$ toxicity and its derivatives ${ }^{[67]}$. $\mathrm{SO}_{2}$ causes oxidative damage to cells and tissues by increasing the content of lipid peroxides in the heart ${ }^{[67]}$. $\mathrm{SO}_{2}$-dependent oxidative damage to several organs, including the heart in mice was also observed ${ }^{[74]} . \mathrm{SO}_{2}$ and its derivatives also can cause DNA damage ${ }^{[75]}$. Protein oxidative damage and DNA-protein crosslinks induced by $\mathrm{SO}_{2}$ have been demonstrated and protein carbonyl content and DNA-protein crosslinks coefficient were used as markers to determine the $\mathrm{SO}_{2}$-induced damage in lungs, livers, and hearts from mice. Protein carbonyl content is the most general indicator of oxidative protein damage ${ }^{[76]}$. DNA-protein crosslinks are thought to be important genotoxic lesions induced by environmental agents and carcinogens and, unlike other DNA lesions that are readily repaired, are relatively persistent ${ }^{[76,77]}$. Thus $\mathrm{SO}_{2}$ may further promote the progression of injury and disease in the cardiopulmonary system by crosslinking with DNA and proteins ${ }^{[67,74]}$.

\section{Carbon Monoxide}

Carbon monoxide ( $\mathrm{CO}$ ) poisoning is a very common and crucial health concern with serious clinical effects and high morbidity and mortality ${ }^{[78]}$. CO is an odorless, colorless, nonirritating gas generated by incomplete combustion of carbon-containing fuels ${ }^{[79]}$. It binds to hemoglobin with high affinity (200-250 times greater than oxygen) to form carboxyhemoglobin and reduces the $\mathrm{O}_{2}$-carrying capacity of the blood. The cardiovascular system and central nervous system are vulnerable to $\mathrm{CO}$ poisoning because of their high oxygen demand ${ }^{[80]}$. Severe myocardial injury occurs upon CO inhalation (Table 2) ${ }^{[81]}$. 
A population-based longitudinal cohort study was performed in Taiwan in 2015 to determine whether patients with $\mathrm{CO}$ poisoning are associated with higher risk of developing cardiovascular diseases ${ }^{[82]}$. They studied the incidence of arrhythmias, coronary artery diseases and congestive heart failure in CO-poisoned patients. Results of their study showed that $\mathrm{CO}$ poisoning was significantly associated with a higher risk of arrhythmias with only a trend for an association between $\mathrm{CO}$ exposure and coronary artery disease and congestive heart failure. The incidence of all three cardiovascular diseases was higher in patients with coexisting comorbidity or high poisoning severity ${ }^{[82]}$.

Other studies show that $\mathrm{CO}$ poisoning can cause ischemia and myocardial injury (elevated troponin I, creatine kinase-MB fraction) and left ventricular dysfunction ${ }^{[83]}$. Heart-type fatty acid-binding protein (h-FABP) is a member of the fatty acid-binding protein family in serum with low molecular weight that is released from the injured myocardium ${ }^{[84]}$. It can be detected within 20 minutes after cardiac damage. It peaks at 3 to 4 hours and returns to reference range in 24 hours ${ }^{[85]}$. Recently, elevated serum hFABP levels were reported in CO-poisoned rats ${ }^{[86]}$. Studies show that it can be used as a novel biomarker of $\mathrm{CO}$ poisoning in humans as well translating into ST segment elevations and depressions on electrocardiogram (EKG) [70, 84]. CO poisoning also caused damage to the cardiac conduction system (dromotropic effects) manifested on the cardiac electrocardiogram (EKG) as T wave inversions and first degree atrioventricular block ${ }^{[87]}$. CO-induced cardiac toxicity was elegantly highlighted in a recent review by Cardiga et al., ${ }^{81]}$.

\section{Ozone}

Ozone $\left(\mathrm{O}_{3}\right)$ is a major oxidative pollutant that causes respiratory damage, airway inflammation and exacerbation of pulmonary diseases such as asthma and cystic fibrosis ${ }^{[88]} . \mathrm{O}_{3}$ can cause oxidation/peroxidation of biomolecules directly or via free radical reactions ${ }^{[89,90]}$. Cell injury/death can result from lipid peroxidation, free radical formation, loss of enzyme activity, and alteration of cell membrane permeability ${ }^{[89]}$.

It has been shown that long-term exposure to ozone in highly polluted areas is associated with cardiovascular morbidity (coronary artery disease, myocardial infarction, atherosclerosis) and mortality ${ }^{[91,92]}$ (Table 2). The combination of $\mathrm{O}_{3}$ and ambient particulate matter in polluted areas can cause vasoconstriction and diastolic hypertension ${ }^{[93,94]}$. In animal models $\mathrm{O}_{3}$ exposure results in increased atherosclerotic plaque size and enhanced susceptibility to ischemic injury [95] [96]. Farraj et al., showed that $\mathrm{O}_{3}$ results in autonomic modulation of cardiac function in rats ${ }^{[97]}$. This modulation of autonomic balance is concentration-dependent and includes bradycardia, PR interval prolongation, ST segment depression, substantial increases in premature atrial beats, sinoatrial block, and atrioventricular block, accompanied by concurrent increases in heart rate variability suggestive of increased parasympathetic tone ${ }^{[97]}$. Similarly, short term $\mathrm{O}_{3}$ exposure of human subjects at environmentally relevant concentration may or may not demonstrate cardiac effects but do suggest that in vulnerable populations (e.g. those with preexisting cardiac disease) such exposures may cause fatal cardiovascular dysfunction ${ }^{[98,99]}$. 
In health, cardiopulmonary interaction is crucial in providing tissues with oxygenated blood. However, under toxic gas/halogen inhalation, these interactions may damage either and to other organs. Added to the challenge, each of cardiac and pulmonary dysfunction may present clinically similarly. Given the independent and potentially fatal cardiac toxicity of these halogens, it is therefore crucial to have a high index of suspicion of cardiac involvement with every halogen or toxic gas exposure.

\section{Acknowledgements}

The authors would like to thank Ms. Gloria Y. Son for editing the manuscript. This work was funded by Intramural funds from the Department of Anesthesiology and Perioperative Medicine (SA) and NIH R01\# HL114933 (AA). This work is also supported by the CounterACT Program, National Institutes of Health Office of the Director (NIH OD), and the National Institute of Neurological Disorders and Stroke (NINDS), Grant Numbers (5U01ES015676-05, 5R21 ES024027 02 and 1R21ES025423 01, SM). This work was also supported in part by funding from the Division of Intramural Research, National Institute of Environmental Health Sciences, NIH. This research also was supported by the CounterACT Program, National Institutes of Health (NIH), Office of the Director, and the National Institute of Environmental Health Sciences (NIEHS), U01ES025069, (AA).

\section{References}

1. Ahmad S, Ahmad A, Hendry-Hofer TB, Loader JE, Claycomb WC, Mozziconacci O, et al. Sarcoendoplasmic reticulum ca(2+) ATPase A critical target in chlorine inhalation-induced cardiotoxicity. Am J Respir Cell Mol Biol. 2015; 52:492-502. [PubMed: 25188881]

2. Damiani RM, Piva MO, Petry MR, Saldiva PH, Tavares Duarte de Oliveira A, Rhoden CR. Is cardiac tissue more susceptible than lung to oxidative effects induced by chronic nasotropic instillation of residual oil fly ash (ROFA)? Toxicol Mech Methods. 2012; 22:533-539. [PubMed: 22563929]

3. Costa VM, Carvalho F, Duarte JA, Bastos Mde L, Remiao F. The heart as a target for xenobiotic toxicity: the cardiac susceptibility to oxidative stress. Chem Res Toxicol. 2013; 26:1285-1311. [PubMed: 23902227]

4. Dedkova EN, Seidlmayer LK, Blatter LA. Mitochondria-mediated cardioprotection by trimetazidine in rabbit heart failure. J Mol Cell Cardiol. 2013; 59:41-54. [PubMed: 23388837]

5. Sedlic F, Sepac A, Pravdic D, Camara AK, Bienengraeber M, Brzezinska AK, et al. Mitochondrial depolarization underlies delay in permeability transition by preconditioning with isoflurane: roles of ROS and Ca2+ Am J Physiol Cell Physiol. 2010; 299:C506-C515. [PubMed: 20519447]

6. Yun Y, Hou L, Sang N. SO(2) inhalation modulates the expression of pro-inflammatory and proapoptotic genes in rat heart and lung. J Hazard Mater. 2011; 185:482-488. [PubMed: 20951496]

7. Yancey DM, Guichard JL, Ahmed MI, Zhou L, Murphy MP, Johnson MS, et al. Cardiomyocyte mitochondrial oxidative stress and cytoskeletal breakdown in the heart with a primary volume overload. Am J Physiol Heart Circ Physiol. 2015; 308:H651-H663. [PubMed: 25599572]

8. Lazrak A, Creighton JR, Yu Z, Komarova S, Doran SF, Aggarwal S, et al. Hyaluronan mediates airway hyper-responsiveness in oxidative lung injury. Am J Physiol Lung Cell Mol Physiol. 2015; 308:L891-L903. [PubMed: 25747964]

9. Weiss SM, Lakshminarayan S. Acute inhalation injury. Clin Chest Med. 1994; 15:103-116. [PubMed: 8200187]

10. Mohan A, Kumar SN, Rao MH, Bollineni S, Manohar IC. Acute accidental exposure to chlorine gas: clinical presentation, pulmonary functions and outcomes. Indian J Chest Dis Allied Sci. 2010; 52:149-152. [PubMed: 20949733]

11. Guloglu C, Kara IH, Erten PG. Acute accidental exposure to chlorine gas in the Southeast of Turkey: a study of 106 cases. Environ Res. 2002; 88:89-93. [PubMed: 11908933]

12. Winder C. The toxicology of chlorine. Environ Res. 2001; 85:105-114. [PubMed: 11161660]

13. Goozner B, Lutwick LI, Bourke E. Chemical terrorism: a primer for 2002. J Assoc Acad Minor Phys. 2002; 13:14-18. [PubMed: 11852665] 
14. White CW, Martin JG. Chlorine gas inhalation: human clinical evidence of toxicity and experience in animal models. Proc Am Thorac Soc. 2010:257-263. [PubMed: 20601629]

15. Ahmad S, Ahmad A, Neeves KB, Hendry-Hofer T, Loader JE, White CW, et al. In vitro cell culture model for toxic inhaled chemical testing J Vis Exp. 2014; 87:e51539.

16. Tuck SA, Ramos-Barbon D, Campbell H, McGovern T, Karmouty-Quintana H, Martin JG. Time course of airway remodelling after an acute chlorine gas exposure in mice. Respir Res. 2008; 9:61. [PubMed: 18702818]

17. Leikauf GD, Pope-Varsalona H, Concel VJ, Liu P, Bein K, Berndt A, et al. Integrative assessment of chlorine-induced acute lung injury in mice. Am J Respir Cell Mol Biol. 2012; 47:234-244. [PubMed: 22447970]

18. Leikauf GD, Pope-Varsalona H, Concel VJ, Liu P, Bein K, Brant KA, et al. Functional genomics of chlorine-induced acute lung injury in mice. Proc Am Thorac Soc. 2010; 7:294-296. [PubMed: 20601635]

19. Lemiere C, Malo JL, Boutet M. Reactive airways dysfunction syndrome due to chlorine: sequential bronchial biopsies and functional assessment. Eur Respir J. 1997; 10:241-244. [PubMed: 9032521]

20. Luo S, Trubel H, Wang C, Pauluhn J. Phosgene- and chlorine-induced acute lung injury in rats: Comparison of cardiopulmonary function and biomarkers in exhaled breath. Toxicology. 2014; 326:109-118. [PubMed: 25456270]

21. Mackie E, Svendsen E, Grant S, Michels JE, Richardson WH. Management of chlorine gas-related injuries from the Graniteville, South Carolina, train derailment. Disaster Med Public Health Prep. 2014; 8:411-416. [PubMed: 25225966]

22. Mangat HS, Stewart TL, Dibden L, Tredget EE. Complications of chlorine inhalation in a pediatric chemical burn patient: a case report. J Burn Care Res. 2012; 33:e216-e221. [PubMed: 22665132]

23. Martin JG, Campbell HR, Iijima H, Gautrin D, Malo JL, Eidelman DH, et al. Chlorine-induced injury to the airways in mice. Am J Respir Crit Care Med. 2003; 168:568-574. [PubMed: 12724121]

24. McGovern TK, Goldberger M, Allard B, Farahnak S, Hamamoto Y, O'Sullivan M, et al. Neutrophils mediate airway hyperresponsiveness after chlorine-induced airway injury in the mouse. Am J Respir Cell Mol Biol. 2015; 52:513-522. [PubMed: 25192041]

25. McGovern TK, Powell WS, Day BJ, White CW, Govindaraju K, Karmouty-Quintana H, et al. Dimethylthiourea protects against chlorine induced changes in airway function in a murine model of irritant induced asthma. Respir Res. 2010; 11:138. [PubMed: 20925946]

26. Mo Y, Chen J, Humphrey DM Jr, Fodah RA, Warawa JM, Hoyle GW. Abnormal epithelial structure and chronic lung inflammation after repair of chlorine-induced airway injury. Am $\mathbf{J}$ Physiol Lung Cell Mol Physiol. 2015; 308:L168-L178. [PubMed: 25398987]

27. Mo Y, Chen J, Schlueter CF, Hoyle GW. Differential susceptibility of inbred mouse strains to chlorine-induced airway fibrosis. Am J Physiol Lung Cell Mol Physiol. 2013; 304:L92-L102. [PubMed: 23171502]

28. Musah S, Chen J, Hoyle GW. Repair of tracheal epithelium by basal cells after chlorine-induced injury. Respir Res. 2012; 13:107. [PubMed: 23170909]

29. O'Koren EG, Hogan BL, Gunn MD. Loss of basal cells precedes bronchiolitis obliterans-like pathological changes in a murine model of chlorine gas inhalation. Am J Respir Cell Mol Biol. 2013; 49:788-797. [PubMed: 23742075]

30. Honavar J, Samal AA, Bradley KM, Brandon A, Balanay J, Squadrito GL, et al. Chlorine gas exposure causes systemic endothelial dysfunction by inhibiting endothelial nitric oxide synthasedependent signaling. Am J Respir Cell Mol Biol. 2011; 45:419-425. [PubMed: 21131444]

31. Zarogiannis SG, Jurkuvenaite A, Fernandez S, Doran SF, Yadav AK, Squadrito GL, et al. Ascorbate and deferoxamine administration after chlorine exposure decrease mortality and lung injury in mice. Am J Respir Cell Mol Biol. 2011; 45:386-392. [PubMed: 21131440]

32. Zarogiannis SG, Wagener BM, Basappa S, Doran S, Rodriguez CA, Jurkuvenaite A, et al. Postexposure aerosolized heparin reduces lung injury in chlorine-exposed mice. Am J Physiol Lung Cell Mol Physiol. 2014; 307:L347-L354. [PubMed: 25038191] 
33. Van Sickle D, Wenck MA, Belflower A, Drociuk D, Ferdinands J, Holguin F, et al. Acute health effects after exposure to chlorine gas released after a train derailment. Am J Emerg Med. 2009; 27:1-7. [PubMed: 19041527]

34. Leustik M, Doran S, Bracher A, Williams S, Squadrito GL, Schoeb TR, et al. Mitigation of chlorine-induced lung injury by low-molecular-weight antioxidants. Am J Physiol Lung Cell Mol Physiol. 2008; 295:L733-L743. [PubMed: 18708632]

35. Folkes LK, Candeias LP, Wardman P. Kinetics and mechanisms of hypochlorous acid reactions. Arch Biochem Biophys. 1995; 323:120-126. [PubMed: 7487057]

36. Weill H, George R, Schwarz M, Ziskind M. Late evaluation of pulmonary function after acute exposure to chlorine gas. Am Rev Respir Dis. 1969; 99:374-379. [PubMed: 5765629]

37. D'Alessandro A, Kuschner W, Wong H, Boushey HA, Blanc PD. Exaggerated responses to chlorine inhalation among persons with nonspecific airway hyperreactivity Chest. 1996; 109:331337. [PubMed: 8620701]

38. Nodelman V, Ultman JS. Longitudinal distribution of chlorine absorption in human airways: a comparison to ozone absorption. J Appl Physiol. 1999; 87:2073-2080. [PubMed: 10601152]

39. Samal A, Honovar J, White CR, Patel RP. Potential for chlorine gas-induced injury in the extrapulmonary vasculature. Proc Am Thorac Soc. 2010; 7:290-293. [PubMed: 20601634]

40. Li B, Jia L, Shao D, Liu H, Nie S, Tang W, et al. Pneumomediastinum from acute inhalation of chlorine gas in 2 young patients. Am J Emerg Med. 2011; 29:357.e351-357.e354. [PubMed: 20627215]

41. Wang J, Abu-Zidan FM, Walther SM. Effects of prone and supine posture on cardiopulmonary function after experimental chlorine gas lung injury. Acta Anaesthesiol Scand. 2002; 46:10941102. [PubMed: 12366504]

42. Kose A, Kose B, Acikalin A, Gunay N, Yildirim C. Myocardial infarction, acute ischemic stroke, and hyperglycemia triggered by acute chlorine gas inhalation. Am J Emerg Med. 2009; 27 :e1021e1024.

43. Gunnarsson M, Walther SM, Seidal T, Bloom GD, Lennquist S. Exposure to chlorine gas: effects on pulmonary function and morphology in anaesthetised and mechanically ventilated pigs. J Appl Toxicol. 1998; 18:249-255. [PubMed: 9719424]

44. Zaky A, Bradley WE, Lazrak A, Zafar I, Doran S, Ahmad A, et al. Chlorine inhalation-induced myocardial depression and failure. Physiol Rep. 2015; 3:e12439. [PubMed: 26109193]

45. Munzel T, Sinning C, Post F, Warnholtz A, Schulz E. Pathophysiology, diagnosis and prognostic implications of endothelial dysfunction. Ann Med. 2008; 40:180-196. [PubMed: 18382884]

46. Daugherty A, Dunn JL, Rateri DL, Heinecke JW. Myeloperoxidase, a catalyst for lipoprotein oxidation, is expressed in human atherosclerotic lesions. J Clin Invest. 1994; 94:437-444. [PubMed: 8040285]

47. Podrez EA, Abu-Soud HM, Hazen SL. Myeloperoxidase-generated oxidants and atherosclerosis. Free Radic Biol Med. 2000; 28:1717-1725. [PubMed: 10946213]

48. Nicholls SJ, Hazen SL. Myeloperoxidase, modified lipoproteins, and atherogenesis. J Lipid Res. 2009; 50(Suppl):S346-S351. [PubMed: 19091698]

49. Pattison DI, Davies MJ. Evidence for rapid inter- and intramolecular chlorine transfer reactions of histamine and carnosine chloramines: implications for the prevention of hypochlorous-acidmediated damage. Biochemistry. 2006; 45:8152-8162. [PubMed: 16800640]

50. Capel RA, Terrar DA. The importance of $\mathrm{Ca}(2+)$-dependent mechanisms for the initiation of the heartbeat. Front Physiol. 2015; 6:80. [PubMed: 25859219]

51. Santulli G, Xie W, Reiken SR, Marks AR. Mitochondrial calcium overload is a key determinant in heart failure. Proc Natl Acad Sci U S A. 2015; 112:11389-11394. [PubMed: 26217001]

52. Gorlach A, Bertram K, Hudecova S, Krizanova O. Calcium and ROS: A mutual interplay. Redox Biol. 2015; 6 REDOXD1500102.

53. Gladden JD, Ahmed MI, Litovsky SH, Schiros CG, Lloyd SG, Gupta H, et al. Oxidative stress and myocardial remodeling in chronic mitral regurgitation. Am J Med Sci. 2011; 342:114-119. [PubMed: 21795957]

54. Cook NL, Viola HM, Sharov VS, Hool LC, Schoneich C, Davies MJ. Myeloperoxidase-derived oxidants inhibit sarco/endoplasmic reticulum $\mathrm{Ca} 2+-\mathrm{ATPase}$ activity and perturb $\mathrm{Ca} 2+$ homeostasis 
in human coronary artery endothelial cells. Free Radic Biol Med. 2012; 52:951-961. [PubMed: 22214747]

55. Liu TC, Ismail S, Brennan O, Hastings C, Duffy GP. Encapsulation of cardiac stem cells in superoxide dismutase-loaded alginate prevents doxorubicin-mediated toxicity. J Tissue Eng Regen Med. 2013; 7:302-311. [PubMed: 22213742]

56. Makarovsky I, Markel G, Hoffman A, Schein O, Brosh-Nissimov TM, Finkelstien A, et al. Bromine--the red cloud approaching. Isr Med Assoc J. 2007; 9:677-679. [PubMed: 17939634]

57. Woolf A, Shannon M. Reactive airways dysfunction and systemic complaints after mass exposure to bromine. Environ Health Perspect. 1999; 107:507-509. [PubMed: 10339453]

58. Inagaki N, Ishikawa M, Takeda M, Abe M, Imai K, Kadoyama T, et al. Case with bromine exposure leading to respiratory insufficiency. Chudoku Kenkyu. 2005; 18:141-147. [PubMed: 16045175]

59. Sagi A, Baruchin AM, Ben-Yakar Y, Kon M, Eyal A, Mahler D. Burns caused by bromine and some of its compounds. Burns Incl Therm Inj. 1985; 11:343-350. [PubMed: 2862974]

60. Bitron MD, Aharonson EF. Delayed mortality of mice following inhalation of acute doses of CH2O, SO2Cl2, and Br2. Am Ind Hyg Assoc J. 1978; 39:129-138. [PubMed: 565136]

61. Hustinx WN, van de Laar RT, van Huffelen AC, Verwey JC, Meulenbelt J, Savelkoul TJ. Systemic effects of inhalational methyl bromide poisoning: a study of nine cases occupationally exposed due to inadvertent spread during fumigation. Br J Ind Med. 1993; 50:155-159. [PubMed: 8435348]

62. Soremark R. Distribution and kinetics of bromide ions in the mallalian body: some experimental investigations using Br80m and Br82. Acta Radiol Suppl. 1960; 190:1-114. [PubMed: 13832871]

63. Rumana HS, Sharma RC, Beniwal V, Sharma AK. A retrospective approach to assess human health risks associated with growing air pollution in urbanized area of Thar Desert, western Rajasthan, India. J Environ Health Sci Eng. 2014; 12:23. [PubMed: 24406114]

64. Liu Y, Chen X, Huang S, Tian L, Lu Y, Mei Y, et al. Association between air pollutants and cardiovascular disease mortality in Wuhan, China. Int J Environ Res Public Health. 2015; 12:3506-3516. [PubMed: 25815523]

65. Rall DP. Review of the health effects of sulfur oxides. Environ Health Perspect. 1974; 8:97-121. [PubMed: 4470921]

66. Shapiro R. Genetic effects of bisulfite (sulfur dioxide). Mutat Res. 1977; 39:149-175. [PubMed: 405577]

67. Meng Z. Oxidative damage of sulfur dioxide on various organs of mice: sulfur dioxide is a systemic oxidative damage agent. Inhal Toxicol. 2003; 15:181-195. [PubMed: 12528046]

68. Meng Z, Liu Y. Cell morphological ultrastructural changes in various organs from mice exposed by inhalation to sulfur dioxide. Inhal Toxicol. 2007; 19:543-551. [PubMed: 17497532]

69. Katsouyanni K, Touloumi G, Spix C, Schwartz J, Balducci F, Medina S, et al. Short-term effects of ambient sulphur dioxide and particulate matter on mortality in 12 European cities: results from time series data from the APHEA project. Air Pollution and Health: a European Approach. Bmj. 1997; 314:1658-1663. [PubMed: 9180068]

70. Acikalin A, Satar S, Sebe A, Kose A, Akpinar O. H-FABP in cases of carbon monoxide intoxication admitted to the emergency room. Hum Exp Toxicol. 2011; 30:443-447. [PubMed: 21075804]

71. Routledge HC, Manney S, Harrison RM, Ayres JG, Townend JN. Effect of inhaled sulphur dioxide and carbon particles on heart rate variability and markers of inflammation and coagulation in human subjects. Heart. 2006; 92:220-227. [PubMed: 15923279]

72. Fedde MR, Kuhlmann WD. Cardiopulmonary responses to inhaled sulfur dioxide in the chicken. Poult Sci. 1979; 8:1584-1591. [PubMed: 537987]

73. Xu J, Zhao M, Liao S. Establishment and pathological study of models of chronic obstructive pulmonary disease by SO2 inhalation method. Chin Med J (Engl). 2000; 113:213-216. [PubMed: 11775248]

74. Meng Z, Qin G, Zhang B, Geng H, Bai Q, Bai W, et al. Oxidative damage of sulfur dioxide inhalation on lungs and hearts of mice. Environ Res. 2003; 93:285-292. [PubMed: 14615239] 
75. Meng Z, Qin G, Zhang B. DNA damage in mice treated with sulfur dioxide by inhalation. Environ Mol Mutagen. 2005; 46:150-155. [PubMed: 15898097]

76. Xie J, Fan R, Meng Z. Protein oxidation and DNA-protein crosslink induced by sulfur dioxide in lungs, livers, and hearts from mice. Inhal Toxicol. 2007; 19:759-765. [PubMed: 17613084]

77. Oleinick NL, Chiu SM, Ramakrishnan N, Xue LY. The formation, identification, and significance of DNA-protein cross-links in mammalian cells. Br J Cancer Suppl. 1987; 8:135-140. [PubMed: 3477283]

78. Kalay N, Ozdogru I, Cetinkaya Y, Eryol NK, Dogan A, Gul I, et al. Cardiovascular effects of carbon monoxide poisoning. Am J Cardiol. 2007; 99:322-324. [PubMed: 17261390]

79. Omaye ST. Metabolic modulation of carbon monoxide toxicity. Toxicology. 2002; 180:139-150. [PubMed: 12324190]

80. Gorman D, Drewry A, Huang YL, Sames C. The clinical toxicology of carbon monoxide. Toxicology. 2003; 187:25-38. [PubMed: 12679050]

81. Cardiga R, Proenca M, Carvalho C, Costa L, Botella A, Marques F, et al. What do we know about carbon monoxide poisoning and cardiac compromise? Rev Port Cardiol. 2015:S0870-S2551. [PubMed: 26232341]

82. Lee FY, Chen WK, Lin CL, Kao CH. Carbon monoxide poisoning and subsequent cardiovascular disease risk: a nationwide population-based cohort study. Medicine (Baltimore). 2015; 94:e624. [PubMed: 25761191]

83. Kara H, Bayir A, Ak A, Degirmenci S. Cerebrovascular ischaemia after carbon monoxide intoxication. Singapore Med J. 2015; 56:e26-e28. [PubMed: 25715861]

84. Erenler AK, Yardan T, Baydin A, Gunay M, Amanvermez R. Heart-type fatty acid-binding protein as a potential biomarker of acute carbon monoxide poisoning. Am J Emerg Med. 2013; 31:11651169. [PubMed: 23809096]

85. Kleine AH, Glatz JF, Van Nieuwenhoven FA, Van der Vusse GJ. Release of heart fatty acidbinding protein into plasma after acute myocardial infarction in man. Mol Cell Biochem. 1992; 116:155-162. [PubMed: 1480144]

86. Yardan T, Meric M, Bozkurt A, Bilge S, Bas DB, Bedir A, et al. The role of heart-type fatty acidbinding protein in the evaluation of carbon monoxide poisoning in rats. Hum Exp Toxicol. 2011; 30:124-128. [PubMed: 20375122]

87. Asgharian Rezaee M, Moallem SA, Imenshahidi M, Farzadnia M, Mohammadpour AH. Effects of erythropoietin on electrocardiogram changes in carbon monoxide poisoning: an experimental study in rats. Iran J Pharm Res. 2012; 11:1191-1199. [PubMed: 24250553]

88. Hollingsworth JW, Kleeberger SR, Foster WM. Ozone and pulmonary innate immunity. Proc Am Thorac Soc. 2007; 4:240-246. [PubMed: 17607006]

89. Mustafa MG. Biochemical basis of ozone toxicity. Free Radic Biol Med. 1990; 9:245-265. [PubMed: 2272533]

90. Pryor WA. Mechanisms of radical formation from reactions of ozone with target molecules in the lung. Free Radic Biol Med. 1994; 17:451-465. [PubMed: 7835752]

91. Srebot V, Gianicolo EA, Rainaldi G, Trivella MG, Sicari R. Ozone and cardiovascular injury. Cardiovasc Ultrasound. 2009; 7:30. [PubMed: 19552797]

92. Jerrett M, Burnett RT, Pope CA 3rd, Ito K, Thurston G, Krewski D, et al. Long-term ozone exposure and mortality. N Engl J Med. 2009; 360:1085-1095. [PubMed: 19279340]

93. Brook RD, Brook JR, Urch B, Vincent R, Rajagopalan S, Silverman F. Inhalation of fine particulate air pollution and ozone causes acute arterial vasoconstriction in healthy adults. Circulation. 2002; 105:1534-1536. [PubMed: 11927516]

94. Fakhri AA, Ilic LM, Wellenius GA, Urch B, Silverman F, Gold DR, et al. Autonomic effects of controlled fine particulate exposure in young healthy adults: effect modification by ozone. Environ Health Perspect. 2009; 117:1287-1292. [PubMed: 19672410]

95. Chuang GC, Yang Z, Westbrook DG, Pompilius M, Ballinger CA, White CR, et al. Pulmonary ozone exposure induces vascular dysfunction, mitochondrial damage, and atherogenesis. Am J Physiol Lung Cell Mol Physiol. 2009; 297:L209-L216. [PubMed: 19395667]

96. Perepu RS, Garcia C, Dostal D, Sethi R. Enhanced death signaling in ozone-exposed ischemicreperfused hearts. Mol Cell Biochem. 2010; 336:55-64. [PubMed: 19809794] 
97. Farraj AK, Hazari MS, Winsett DW, Kulukulualani A, Carll AP, Haykal-Coates N, et al. Overt and latent cardiac effects of ozone inhalation in rats: evidence for autonomic modulation and increased myocardial vulnerability. Environ Health Perspect. 2012; 120:348-354. [PubMed: 22138703]

98. Arjomandi M, Wong H, Donde A, Frelinger J, Dalton S, Ching W, et al. Exposure to medium and high ambient levels of ozone causes adverse systemic inflammatory and cardiac autonomic effects. Am J Physiol Heart Circ Physiol. 2015; 308:H1499-H1509. [PubMed: 25862833]

99. Devlin RB, Duncan KE, Jardim M, Schmitt MT, Rappold AG, Diaz-Sanchez D. Controlled exposure of healthy young volunteers to ozone causes cardiovascular effects. Circulation. 2012; 126:104-111. [PubMed: 22732313]

100. Kose A, Kose B, Acikalin A, Gunay N, Yildirim C. Myocardial infarction, acute ischemic stroke, and hyperglycemia triggered by acute chlorine gas inhalation. Am J Emerg Med. 2009; 27:1022 e1021-1022 e1024. [PubMed: 19857438]

101. Martinez TT, Long C. Explosion risk from swimming pool chlorinators and review of chlorine toxicity. J Toxicol Clin Toxicol. 1995; 33:349-354. [PubMed: 7629902]

102. Meakins JC, Priestley JG. The After Effects of Chlorine Gas Poisoning. Can Med Assoc J. 1919; 9:968-974. [PubMed: 20311346]

103. Liubchenko PN, Alekseeva GA. [Acute poisoning with bromine vapors of a pharmaceutical plant operator]. Gig Tr Prof Zabol. 1991; 9:32-34. [PubMed: 1794718]

104. Gordon CJ, Johnstone AF, Aydin C, Phillips PM, MacPhail RC, Kodavanti UP, et al. Episodic ozone exposure in adult and senescent Brown Norway rats: acute and delayed effect on heart rate, core temperature and motor activity. Inhal Toxicol. 2014; 26:380-390. [PubMed: 24779854]

105. Wagner JG, Allen K, Yang HY, Nan B, Morishita M, Mukherjee B, et al. Cardiovascular depression in rats exposed to inhaled particulate matter and ozone: effects of diet-induced metabolic syndrome. Environ Health Perspect. 2014; 122:27-33. [PubMed: 24169565]

106. Jerrett M, Finkelstein MM, Brook JR, Arain MA, Kanaroglou P, Stieb DM, et al. A cohort study of traffic-related air pollution and mortality in Toronto, Ontario, Canada. Environ Health Perspect. 2009; 117:772-777. [PubMed: 19479020]

107. Shah AS, Langrish JP, Nair H, McAllister DA, Hunter AL, Donaldson K, et al. Global association of air pollution and heart failure: a systematic review and meta-analysis. Lancet. 2013; 382:1039-1048. [PubMed: 23849322]

108. Ureyen CM, Bas CY, Arslan S. Myocardial Infarction after Ozone Therapy: Is Ozone Therapy Dr. Jekyll or Mr. Hyde? Cardiology. 2015; 132:101-104. [PubMed: 26139204]

109. Dragelyte G, Plenta J, Chmieliauskas S, Jasulaitis A, Raudys R, Jovaisa T, et al. Myocardial Rupture following Carbon Monoxide Poisoning. Case Rep Crit Care. 2014; 2014:281701. [PubMed: 25110594]

110. Teksam O, Gumus P, Bayrakci B, Erdogan I, Kale G. Acute cardiac effects of carbon monoxide poisoning in children. Eur J Emerg Med. 2010; 17:192-196. [PubMed: 20195157]

111. Davutoglu V, Gunay N, Kocoglu H, Gunay NE, Yildirim C, Cavdar M, et al. Serum levels of NTProBNP as an early cardiac marker of carbon monoxide poisoning. Inhal Toxicol. 2006; 18:155158. [PubMed: 16393930]

112. Gandini C, Castoldi AF, Candura SM, Priori S, Locatelli C, Butera R, et al. Cardiac damage in pediatric carbon monoxide poisoning. J Toxicol Clin Toxicol. 2001; 39:45-51. [PubMed: 11327226]

113. Jin H, Liu AD, Holmberg L, Zhao M, Chen S, Yang J, et al. The role of sulfur dioxide in the regulation of mitochondrion-related cardiomyocyte apoptosis in rats with isopropylarterenolinduced myocardial injury. Int J Mol Sci. 2013; 14:10465-10482. [PubMed: 23698774]

114. Xie J, He M, Zhu W. Acute effects of outdoor air pollution on emergency department visits due to five clinical subtypes of coronary heart diseases in shanghai, china. J Epidemiol. 2014; 24:452459. [PubMed: 24998952]

115. Amancio CT, Nascimento LF. Association of sulfur dioxide exposure with circulatory system deaths in a medium-sized city in Brazil. Braz J Med Biol Res. 2012; 45:1080-1085. [PubMed: 22892828] 


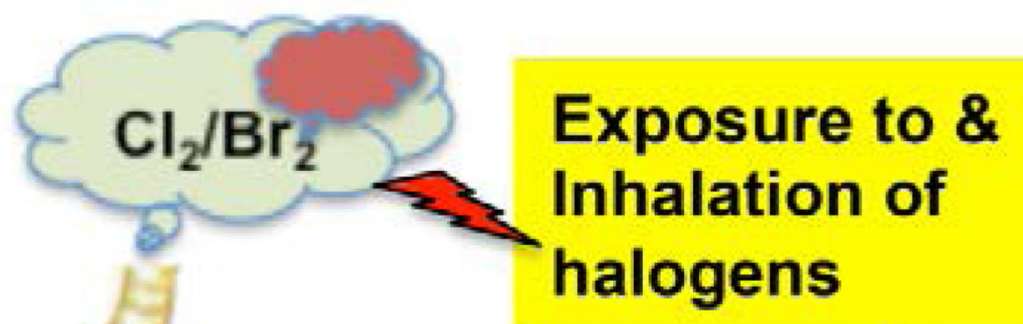

\section{Reactions on moist lung surface}

\section{Circulating reactants reach heart}

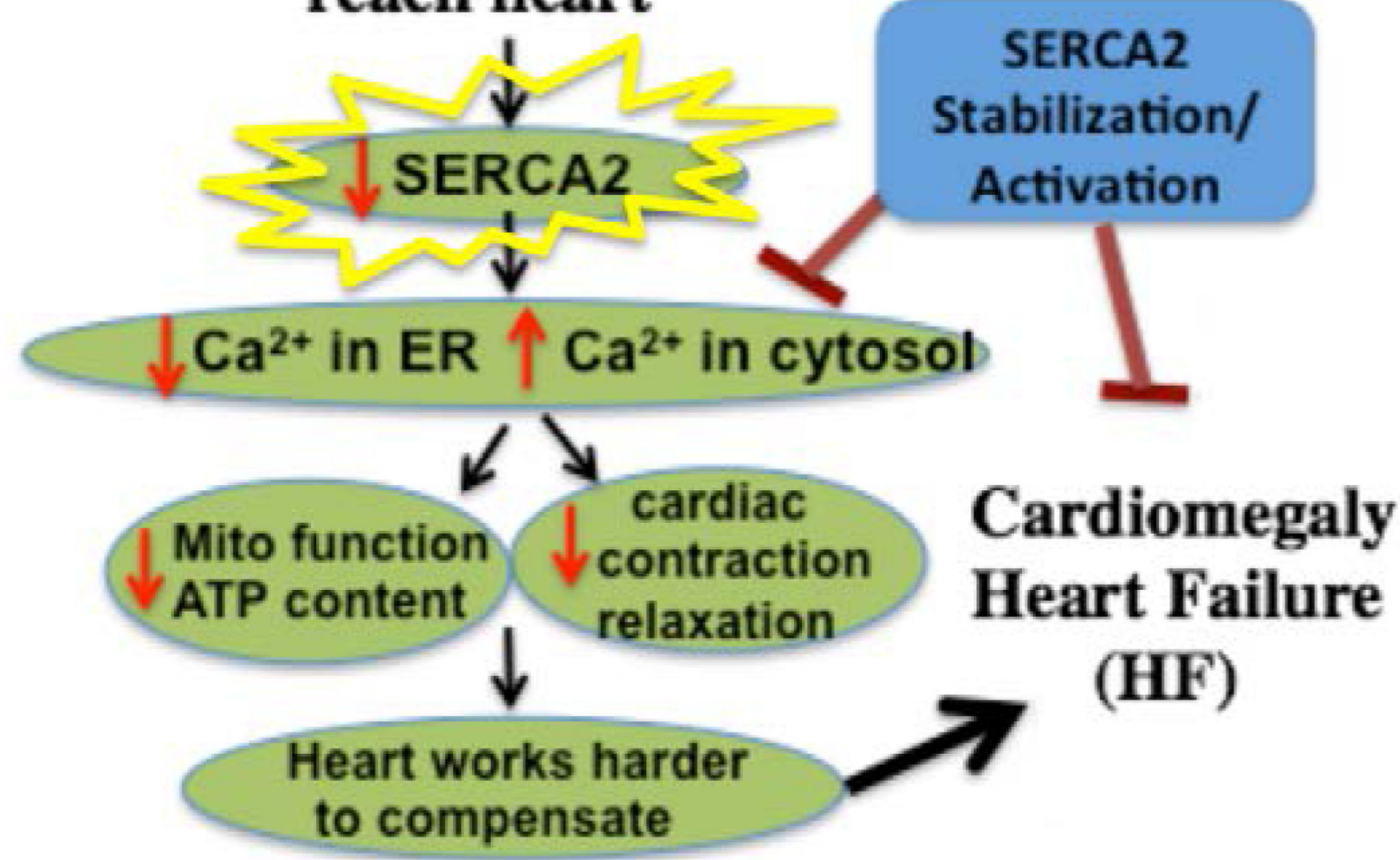

Figure 1. Schematic representation of mechanisms of halogen $\left(\mathrm{Cl}_{2} / \mathrm{Br}_{2}\right)$ gas inhalation-induced cardiotoxicity

Inhaled gases react with the moist surface and form secondary reactants that are absorbed in circulation and travel to the heart. Modification and inactivation of important proteins such as SERCA cause pathologic events such as $\mathrm{Ca}^{2+}$ overload resulting in mitochondrial damage and loss of ATP contents and cardiac dysfunction. Blocking damage to SERCA may be a therapeutic strategy after such toxic exposures. Mito, mitochondria; ER, endoplasmic reticulum; SERCA, sarcoendoplasmic reticulum $\mathrm{Ca}^{2+}$ ATPase 


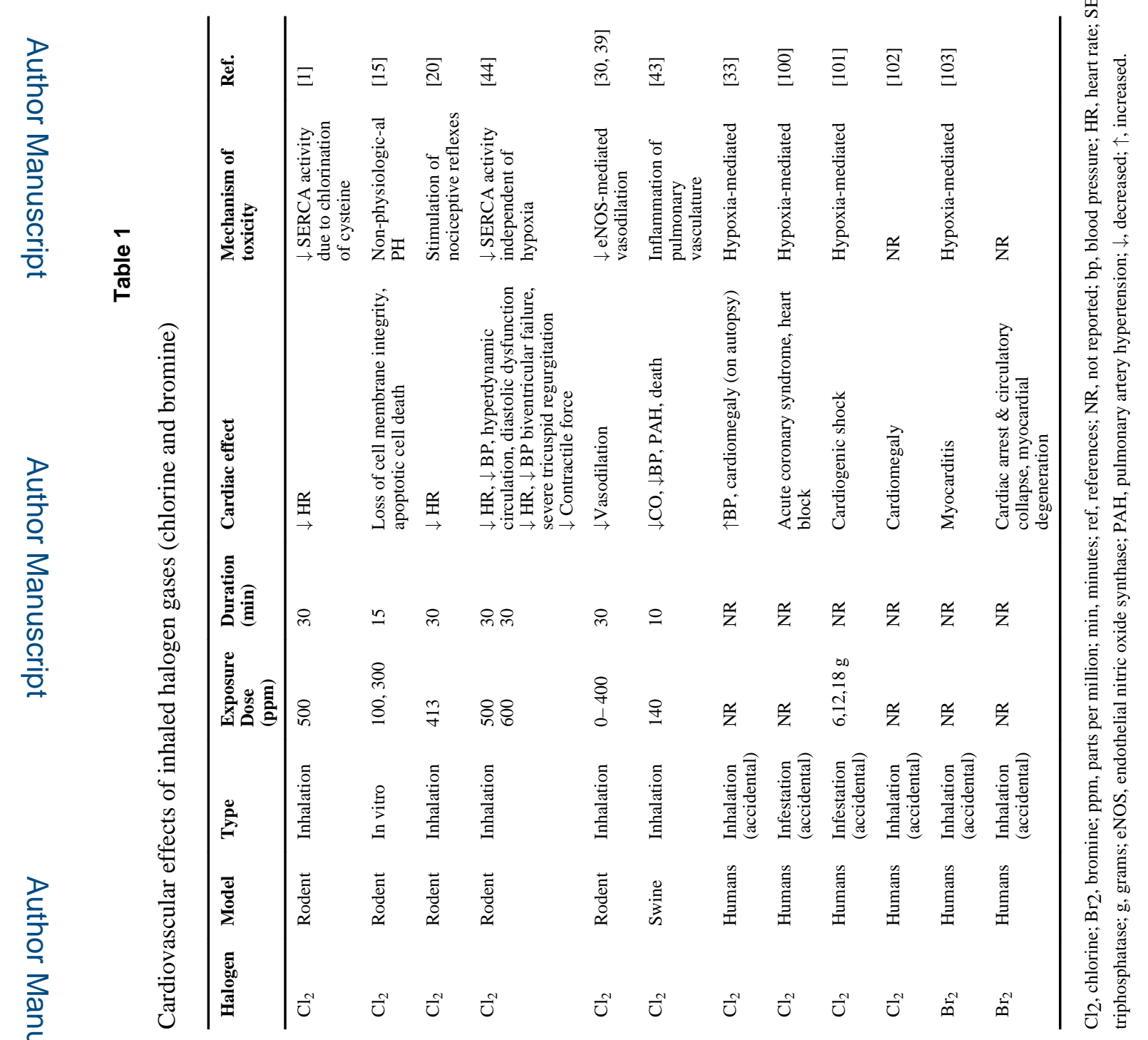




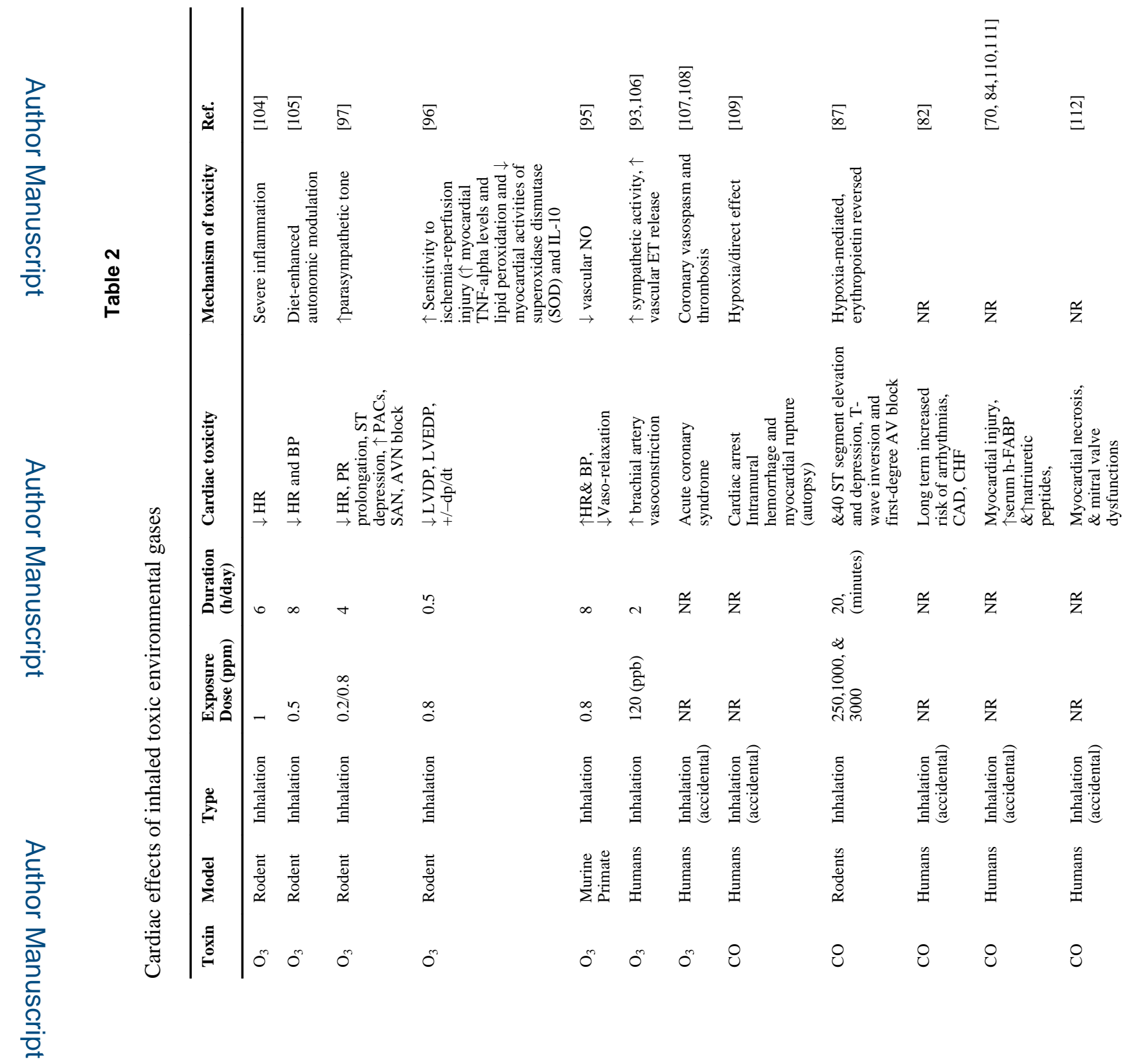




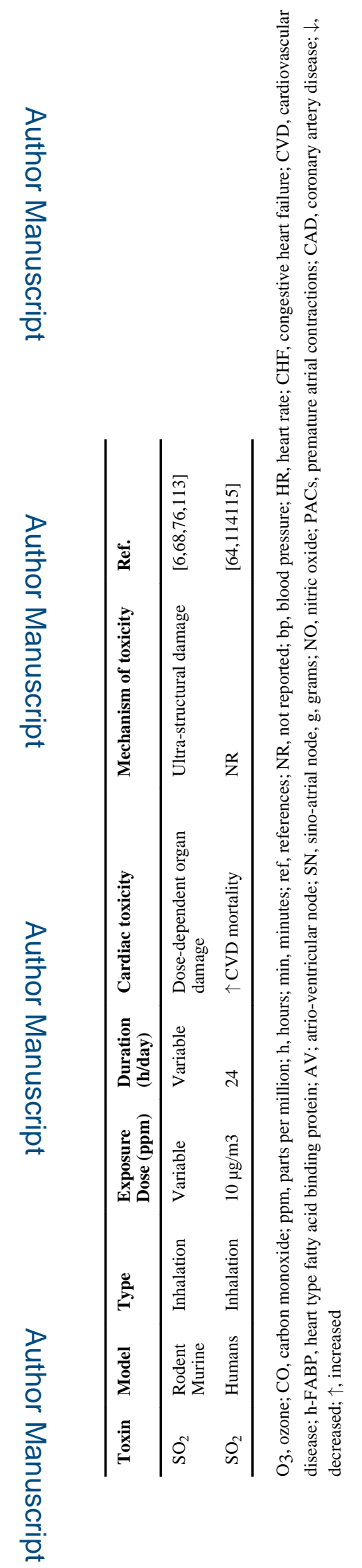

Cardiovasc Regen Med. Author manuscript; available in PMC 2015 December 08. 